\title{
Na era do testemunho
}

\author{
Marli Fantini Scarpelli ${ }^{1}$ \\ (Universidade Federal de Minas Gerais)
}

RESUMO: ESTE TRABALHO INVESTIGA TEXTOS E CONTEXTOS QUE ABORDAM MOMENTOS HISTÓRICOS DE PERIGO TRAZENDO CONSIGO A AMEAÇA CONTRA A INTEGRIDADE DA SOCIEDADE E/OU DOS INDIVÍDUOS. CONFRONTADOS POR ACONTECIMENTOS TRAUMÁTICOS E INASSIMILÁVEIS E FRENTE AO RISCO DE PERDER VALORES, TRADIÇÕES E SUAS PRÓPRIAS VIDAS, UM E OUTRO ASSUMEM MOVIMENTOS DE RESISTÊNCIA E DENÚNCIA, QUE, NO EXTREMO, PODEM PROVOCAR A REVISÃO DE HISTÓRIA INDIVIDUAL E MESMO COLETIVA.

ABSTRACT: THIS WORK INVESTIGATES TEXTS AND CONTEXTS THAT TREAT OF HISTORICAL MOMENTS OF DANGER, WHICH BRING WITHIN THREATS AGAINST INDIVIDUAL AND/OR SOCIAL INTEGRITY. CONFRONTING TRAUMATIC AND INASSIMILABLE FACTS AND THE RISK OF LOSING VALUES, TRADITIONS AND THEIR OWN EXISTENCE, INDIVIDUALS AND SOCIETY ASSUME TO PARTICIPATE IN RESISTANCE AND DENUNCIATION MOVEMENTS WHICH CAN GO AS FAR AS CAUSING INDIVIDUAL AND COLLECTIVE HISTORY REVIEWS.

PALAVRAS-CHAVE: LITERATURA E TRAUMA - TESTEMUNHO - REAL E RELATO - EXPERIÊNCIA E VIVÊNCIA

KEY-WORDS: LITERATURE AND TRAUMA - TESTIMONY - REALITY AND REPORT - EXPERIENCE AND PERCEPCION

1 Marli Fantini Scarpelli é Profa. Associada de Teoria da Literatura e Literatura Comparada da FALE/ UFMG e Pesquisadora do CNPq, com Bolsa em Produtividade em Pesquisa, graças à qual este ensaio pode ser realizado. 
ausência é o primeiro lugar do discurso.

Michel Foucault

Tudo o que eu queria era andar numa terra que não tivesse mapas.

Michael OndaAtje

Marcados por perdas irreparáveis, por feridas não cicatrizadas, muitos indivíduos são atormentadas por inquietação, melancolia ou, segundo expressão de Foucault, "impaciência pela liberdade". O despertar dessas consciências pode muitas vezes reativar a herança de um passado que, não obstante obliterado, continua enfrentando-as como questão, a exigir-lhes a atualização e a conseqüente elaboração de potencialidades irrealizadas. Problematizado por Foucault como um "acontecimento", tal processo tende a manifestar-se como uma "transgressão possível" e, sob esse influxo, a desencadear o fluxo de vozes silenciadas, sancionando, dessa forma, a abertura do pensamento. Abertura como recolha atualizada do já pensado e convocação, ademais, do ainda não pensado, no interior do já pensado. Ao agenciar a constituição do sujeito enquanto ser livre, o "acontecimento" foucaultiano, posto retomar apenas parcial e fragmentariamente experiências de perda e sofrimento, constitui uma "ponta deslocada do presente", cuja astúcia reside na transformação da ausência no "primeiro lugar do discurso" (FOUCAULT, 2006: 31). Justamente a transformação "indispensável para a constituição de nós mesmos como sujeitos autônomos" (EWALD, 1984).

Migrações enormes que derivam da modernidade acelerada, do choque entre civilizações em crescente deslocamento e diáspora, da globalização ou, como Melucci preferia dizer, da "planetarização" (MELUCCI, 2005: 73), do grande mundo do comércio livre e da circulação financeira são, em diversas medidas, responsáveis pela mudança acelerada de uma quantidade antes impensável de indivíduos em gente supérflua. Ao perder qualquer meio de sustento nos lugares em que viviam, tais indivíduos se convertem em imigrantes econômicos e se vêem-se forçados a deslocar-se para as grandes cidades, onde são identificados com as "misteriosas, logo assustadoras, forças da globalização". Vindos não se sabe de onde, além de gerar desconfiança e aversão, esses resíduos populacionais são estigmatizados como "mensageiros de desgraças" e trazem consigo "o horror das guerras remotas, de fomes, 
de privações e representam o nosso pior pesadelo." Isso porque nos fazem temer que nós próprios, "devido à pressão exercida pelo novo e misterioso equilíbrio econômico, possamos perder os meios de sobrevivência e a nossa posição social" (MELUCCI, 2005: 73). Imigrantes em exílio forçado, condenados ao contínuo deslocamento, tornam-se, portanto, a encarnação das diferenças que causam tanto temor e aversão em nós, que, antes de seu invasivo e ameaçador afluxo, vivíamos em segurança nas nossas grandes cidades. Para nos protegermos da indesejada vulnerabilidade, criamos fronteiras no entorno dos downtowns, nos acéticos subúrbios cercados de cercas floridas, nos arrabaldes de nossas cidadelas ameaçadas.

É justamente esse quadro assustador de fronteiras discriminatórias, crescentes na modernidade acelerada, em lugar de gerar livre circulação, se fecham para assegurar o isolamento e a proteção dos que chegaram primeiro às suas cidades (via de regra, as pessoas mais abastadas e seguras em seus nichos residenciais). Sob a postura da indiferença e mesmo da exclusão, estas se protegem do "contágio", ou seja, de qualquer forma de confronto - sempre indesejável - com as "diferenças", com os "outros"; em suma, com os "desclassificados". ${ }^{2}$ Ainda assim, é possível surpreender, mesmo nas assustadas metrópoles, alguma reserva de humanidade naqueles que, de modo surpreendentemente delicado e ético, são capazes de lançar um olhar na direção desses indivíduos solitários e infelizes na sua opacidade; de dizer-lhes aquela palavra suficientemente solidária e amiga a ponto de libertá-los do enclausuramento. A menos que tenham acesso a uma mediação solidária, esses imigrantes da globalização continuarão desamparados e, como judeus errantes, à mercê de sua má sorte. Abandonados por Deus, pelos governos e por aqueles que permanecem trancados em condomínios de luxo - essa espécie de ghettos às avessas, de prisões voluntárias.

Não obstante todos os temores frente a esses temerários "outros", sempre existe, embora rara, alguma reserva de solidariedade. Estando, de certa feita, num metrô de Lisboa, li e anotei esta citação impactante, atribuída a Deleuze:

2 Em decorrência do sentido inumano e cruel para o qual derivou, nos EEUU, a palavra "desclassificado", Bauman identifica nele uma nova conotação, que, a bem da verdade, é extremamente depreciativa. Ser desclassificado passa a significar, doravante, ser supérfluo, estar simplesmente fora do sistema de classes, estar excluído, e não servir para nada. A alternativa que resta a indivíduos nessa condição "é sofrer a discriminação" (BAUMAN, 2005: 79). 
"Ética é estar à altura do que nos acontece". A citação do metrô me provoca algum mal estar no sentido de que não é raro nossa atitude ser de indiferença ou omissão frente a incontáveis acontecimentos que suscitam nossa adesão: são crianças esmolando, um corpo morto a obstruir o tráfego, meninas que, sob o desdém de transeuntes e motoristas, oferecem o corpo em noites frias, pessoas sem teto ou sem país, gente sem saída perambulando nos aeroportos, sempre à inútil espera de um olhar, uma escuta, uma palavra. Muitas vezes de forma deliberada, alheamo-nos frente ao "outro". Sobretudo quando confrontados pelo que nele nos incomoda ou que não diz respeito a nossas estreitas expectativas. Conclusão: se não nos interessam, por estas ou outras razões, os indivíduos pelos quais poderíamos, no sentido ético, ter compaixão (paixão com, empatia, solidariedade) são alijados de nosso campo intersubjetivo. Para falar sem meias-tintas, ficam fora até mesmo do nosso campo perceptivo, visto que, expulsos de qualquer proximidade, tornam-se invisíveis para nós, não lhes sendo dado dirigir-nos a palavra, nem ser vistos, ouvidos ou tocados por nós. Portar-se eticamente consiste, portanto, em mostrar-se à altura da reciprocidade: devolver o olhar que lhe é lançado, ouvir o que lhe necessitam confidenciar, mediar e pontuar narrativas de histórias ultrajadas, conferindo-lhes a legitimidade capaz de devolver-lhes a dignidade.

Ao denunciar e, conseqüentemente, atualizar suas experiências traumáticas, portadores de vozes machucadas, que tiveram a oportunidade fortuita de encontrar mediadores para suas queixas, logram, no extremo, chancelar o desvelamento e, na melhor das hipóteses, a implosão de aparelhos de controle e opressão. Dessa intervenção pode resultar a reconstituição e a renovação de histórias individuais e mesmo coletivas. Embora incomum, semelhante intervenção assoma como um "acontecimento" de desterritorialização e transcendência em que a memória irrompe na consciência, trazendo à luz da presença - quase sempre por apenas um breve instante de fulguração - acontecimentos obliterados, opacos, arruinados. Ao irromper de sua fratura, tais acontecimentos, porque há muito recalcados, resistem à representação no presente. Dado seu caráter rasurado e irresolúvel, a não ser muito rara e parcialmente, chegam a se materializar na atualidade do discurso.

A despeito de traumas, uma vez libertas da "prisão do passado", vozes interditadas com/por seus respectivos corpos podem, tendo em vista as limitações descritas, assomar, imperar e aceitar a convocação para enunciar o 
que "ainda está para ser pensado" (HEIDEGGER, 1984: 187). Dessa forma, ao pronunciar com liberdade (quase sempre parcial) sua voz, o sujeito da enunciação logra, simultaneamente, saltar da insciência para alguma forma de consciência. Para Benjamin, endossando Freud, esse salto marca a passagem da experiência para a vivência (BENJAMIN, 1998: 111); para Beatriz Sarlo, do real para o relato/testemunho (SARLO, 2007: 24-25). Uma vez livre, a vOz enunciadora pode driblar e até mesmo superar seus bloqueios, liberando o pensamento para o futuro e tornando transmissível sua experiência. A possibilidade de expressar uma experiência traumática tende a manifestar-se em momentos de perigo, mas também de relaxamento e superação. Momentos em que, ao sujeito da linguagem (opaca e fragmentária), é-lhe dado, por exemplo, entrar em contato (malgrado muitas vezes fugaz) consigo mesmo e vislumbrar, ainda que provisoriamente, alternativas para suas dificuldades e novas perspectivas para seu vir-a-ser. Ao liberar o presente da prisão do passado, o futuro desponta como possibilidade inesperada.

Os testemunhos de caráter tanto documental quanto ficcional se inserem no gênero narrativo cuja relevância é notável desde o final da Segunda Guerra. Em suas pesquisas sobre o gênero testemunhal, Jaime Ginsburg aponta o século XX como tempo propício ao testemunho, em virtude da enorme presença das guerras e dos genocídios. Para o sujeito enunciador do testemunho, entre o impacto da catástrofe e os recursos expressivos, pode haver um abismo intransponível, de modo que toda formulação pode ser imprecisa ou insuficiente (GINSBURG, 2009). Estes dois adjetivos reforçam um quase inevitável divórcio entre o relato e a experiência do trauma, o qual se dota de um caráter irredutível e, portanto, refratário à representação, ou seja, ao relato.

Ao longo do romance Grande sertão: veredas, de Guimarães Rosa, desenrolase uma entrevista, cujo modo de configurar-se caminha para a estrutura de um relato testemunhal. Quando instado por seu entrevistador/mediador a explicar as razões por que, mesmo décadas depois de "cerradas" suas infernais experiências de pactos, traições, guerras, mortes, luto, nunca as havido relatado, Riobaldo, o entrevistado e, respectivamente, narrador-protagonista do romance, encontra a oportunidade de relatar e atualizar suas experiências. No entanto, paralisado diante pela irredutibilidade do real, cuja resistência a qualquer substituição produz repetições e engasgos em face de qualquer tentativa de "transação metafórica" (AVELAR, 2003: 235), ele precisa antes 
negociar com tempo, feridas, melancolia até que possa dar o salto da experiência para o relato.

Quando é abordado pelo entrevistador que vem de fora, uma espécie de estrangeiro, homem de "suma doutoração" que escuta atentamente seus relatos por três dias, Riobaldo logra saltar o "abismo entre o imperativo irredutível de narrar e a percepção angustiante de que a linguagem não pode expressar completamente tal experiência, de que nenhum interlocutor consegue capturar sua dimensão real, nem sequer escutar o relato com suficiente atenção.” (AVELAR, 2003: 235). No discurso abaixo, malgrado a persistência da melancolia e os tropeços frente ao divórcio entre o vivido e sua representação, é possível notar o percurso que vai da experiência para a vivência, do real para o relato.

De primeiro, eu fazia e mexia, e pensar não pensava. Não possuía os prazos. Vivi puxando difícil de difícel, peixe vivo no moquém: quem mói no asp'ro, não fantasêia. Mas, agora, feita a folga que me vem, e sem pequenos desassossegos, estou de range rede. E me inventei neste gosto, de especular idéia. O diabo existe e não existe? Dou o dito Abrenúncio. Essas melancolias. O senhor vê: existe cachoeira; e pois? Mas cachoeira é barranco de chão, e água se caindo por ele, retombando; o senhor consome essa água, ou desfaz o barranco, sobra cachoeira alguma? Viver é negócio muito perigoso... (ROSA, 1984: 11-12)

\section{Testemunho: uma proposta narrativa para o pós-guerra}

O "testemunho" constitui um novo gênero que diz respeito à relação entre literatura, violência e trauma. Gênero literário ou discursivo que traduz bem a modernidade, o "testemunho" se tornou tão central e onipresente depois da Segunda Guerra, que o tempo atual poderia, nas palavras de Shoshana Feldman, ser definido, como a "era do testemunho" (FELDMAN, 2000: 18). Por que a centralidade e a onipresença? Bem provavelmente porque, por meio do testemunho tenta-se dizer o que, via de regra, não se pode dizer. Por conseguinte, o relato testemunhal é um gênero que oferece suporte à representação do irrepresentável, um discurso capaz de desencadear uma rede de solidariedade entre vítimas de opressão, violência e toda sorte de traumas. Assim sendo, o testemunho desponta como um gênero narrativo por meio do qual 
se pode dizer o interdito, o horror, a dor da perda irremediável. Embora de forma precária e insuficiente, o testemunho faz vir à tona "fragmentos, ou cacos esmagados pela força de ocorrências" que, se "nunca chegam nunca a se cristalizar em compreensão ou lembrança” (NESTROVSKI \& SELIGMANN-SILVA, 2000: 10), logram, em contrapartida, acender uma luz no fim da última trincheira. Trincheira a partir de cujo fogo cerrado, onde ainda se tenta sobreviver, oferecendo resistência à violência e ao horror.

Os momentos em que as vozes feridas de vítimas de situações traumáticas se articulam para denunciar a violência e as atrocidades sofridas, seja nos porões das ditaduras latino-americanas, seja nos campos franquistas ou nazistas, têm-se mostrado propícios ao aparecimento de relatos e documentos sobre perseguições, torturas e genocídios. Salienta-se, nesse sentido, a Shoah, designação atribuída ao holocausto judeu, a partir de cujas conseqüências, os poucos sobreviventes tiveram a oportunidade histórica e simbólica de - não obstante a dor, o luto e a culpa quase sempre irremediáveis - revisitar suas experiências de horror e, assim sendo, retomar sua memória pessoal e sua identidade coletiva. ${ }^{3}$ No contexto soviético, assomam os testemunhos do Gulag, que chega a nossos dias como um símbolo inapagável da repressão da ditadura de Stalin.

Dos testemunhos de intelectuais, a exemplo de Orhan Pamuk, prêmio Nobel de Literatura em 2006, chegam notícias há muito ocultadas do massacre encetado pela Turquia contra os armênios. Tudo isso sem nos esquecermos da Bósnia, do Afeganistão, de Angola, Moçambique, Chechênia, Sibéria, Iraque, Ruanda, ataques a reservas indígenas, massacres étnicos, o que faz inevitavelmente do mundo contemporâneo um grande campo de guerra a cujas atrocidades todos estamos eticamente comprometidos.

\section{Mapas de desertos da Segunda Guerra: $O$ paciente inglês}

A esse propósito, ressalta-se o romance O paciente inglês, de Michel Ondaatje, que, ao mesclar ficção e história, logra representar, com viva verossimilhança, os trágicos acontecimentos que rondam a vida de quatro sobreviventes da

3 Ver, a respeito, o filme, Shoah, dirigido por Claude Lanzmann, em 1985, que, por sua vez, desencadeou novas ondas de testemunho e videotestemunhos. 
Segunda Guerra Mundial. Diferentemente do que aponta o título, o protagonista do romance não é inglês. Trata-se de Laszlo Almásy, conde húngaro, um dos três cartógrafos que, em 1930 começam a mapear a maior parte do platô de Gilf Kebir, imenso deserto situado na fronteira entre Egito e a Líbia. Membro da Sociedade Geográfica do Reino Unido, ele sabe de antemão que seus mapas visam a estratégias de poder, e que "um dia o deserto ia ser o teatro de operações de guerra” (ONDAAT'TJE, 2007: 227). Embora dotado(s) dessa convicção (e por causa dela), ele e seus companheiros de deserto foram se tornando "homens sem pátria", "deformados pelo Estado-nação" e com desprezo por todos os governos, todas as identidades e nações:

Todos nós, mesmo os que tinham família e filhos na Europa distante, desejávamos tirar a roupa de nossos países [...] Partíamos do abrigo dos oásis. Os lugares onde a água vinha tocar... Ain, Bir, Wadi, Foggara, Khottara, Shaduf. Não quero que meu nome venha atrapalhar nomes tão maravilhosos. Apagar o nome da família! Apagar as nações! O deserto me ensinou essas coisas [...] Quando veio a guerra, depois de dez anos no deserto, foi fácil, para mim, escapulir pelas beiradas, para não pertencer a ninguém, a nenhuma nação. (ONDAATTJJE, 2007: 126)

Todavia, esse anseio de autonomia frente a identidades marcadas e subjugáveis desemboca na fatalidade que alcança "pelas beiradas" o "paciente inglês". Quando perambula pelo deserto à procura de um avião, é capturado por soldados alemães. Torturado, ele entrega mapas estratégicos do deserto ao "inimigo". Embora húngaro e rejeitando qualquer nacionalidade, Almásy se educou na Inglaterra, domina bem o inglês e é membro da Sociedade Geográfica do Reino Unido. Assim, além de estigmatizado como inimigo das duas frentes de guerra, ele considerado traidor de "sua pátria" - paradoxalmente a Inglaterra.

Tendo escapado dos alemães, consegue finalmente resgatar o corpo da amante já morta, mas o avião por ele pilotado é abatido por fogos antiaéreos. É salvo por nômades do deserto e, tempos depois se encontra, junto a enfermeira e mais dois sobreviventes, numa vila, em Florença. Agonizante, ele relata estilhaços de vida, a paixão por uma mulher casada e a tragédia que daí decorre. A memória do deserto é modulada por lembranças da guerra e reflexões sobre fronteiras isolacionistas entre nações a desencadear disputas, ódios, guerras fratricidas. Em síntese, são tensões realimentadas pelos fun- 
damentalismos a afetar milhões de indivíduos, os quais, sem saber por que, tornam-se inimigos mortais entre si.

Antibelicista, nômade como as tribos do deserto a que ele tanto ama, o "paciente inglês", foi tragicamente vítima dos mapas que ele próprio cartografou. Guardando em seu corpo queimado as marcas do deserto, Almásy, pouco antes de morrer reflete sobre a armadilha para cujo traçado ele próprio contribuiu. Ou seja, as conseqüências dessa cartografia não difere do sentido geopolítico assumido pelas fronteiras. Em lugar de franquear, ambos, mapas e fronteiras, são demarcados sob o influxo de ideologias hegemônicas e discriminatórias que visam justamente ao cerceamento do livre trânsito, da autonomia, da intersubjetividade calcados em relações intersubjetivas e heterogêneas. São, enfim, fronteiras e mapas que, sob o influxo da globalização, vêm, desde a Segunda Guerra, acirrando tensões entre diferenças individuais, nacionais, internacionais. A fala a seguir resulta, nesse sentido, de uma reflexão, e uma denúncia, ambas moduladas pelo soluço de uma voz ferida de guerra.

Desejo que tudo isso fique marcado no corpo quando eu morrer. Acredito nessa cartografia - ser marcado pela natureza, não apenas pôr um rótulo sobre o mapa [...]. Somos histórias comunitárias. Não somos propriedade única de alguém nem monógamos no nosso gosto e na nossa experiência. Tudo que eu queria era andar numa terra que não tivesse mapas. (ONDAATTJE, 2007: 236)

\section{“Testimonios" na América Latina}

Ao debruçar-se no projeto libertador da cultura latino-americana, Angel Rama, intelectual, antropólogo, escritor e ensaísta uruguaio, identifica o surgimento de denúncias de vítimas de atrocidades no continente, por volta da década de 1960. Segundo ele, em correspondência com ocorrências como o Gulag ou o Shoah, vozes antes silenciadas seja por censura, seja por ameaças ou por torturas, irrompem na América Latina sob a forma de relatos e testemunhos. No mais das vezes, trata-se de denúncias pronunciadas por indivíduos oriundos de setores e classes que ocupavam lugares marginais no conglomerado social ou simbólico. Sentindo-se ameaçados diante de mudanças sociais bruscas, a reação de desses indivíduos começa a se esboçar. Tal 
fenômeno já apresenta seus primeiros sinais no início do século XX, quando proletariado e camponeses sul-americanos principiam, nas revoluções socialistas, seus incipientes discursos no fechado e elitista circuito de literatura e cultura hegemônicas, nele influindo com temáticas populares e revolucionárias, até então desprezadas. Rama salienta o posicionamento reativo de classes cultas que consideram tais temáticas um "retrocesso artístico". Todavia, tais manifestações, resultariam, segundo sua adequada percepção, numa "reconversão mais democrática e popular da narrativa” (RAMA, 2001: 104-105).

Ademais dessas manifestações, o intelectual uruguaio identifica nesses discursos "uma forte tendência ao documentarismo, às formas de reportagem quase direta, em carne viva, à literatura testemunhal e à autobiografia mais ou menos encoberta", em literaturas hispano-americanas. Mas não somente nelas. Além de documentar ocorrências similares na literatura mexicana, cubana ou peruana, Rama filtra documentos relevantes na literatura soviética, a exemplo da Cavalaria vermelha, de Isaac Babel ou do Poema pedagógico, de Makarenko. Nesse sentido, ele ressalta que "essa inclinação pela narrativa autobiográfica e pelo documentário não é patrimônio exclusivo das revoluções, mas [...] de toda mudança rápida, tal como estão sendo produzidas no mundo inteiro". Curiosamente, ele destaca a pertinência e a visibilidade de tal inclinação no romance da descolonização africana. Dada a relevância de pesquisa e reflexão nesse campo, seus posicionamentos constituem uma fonte de pesquisa para os estudos sobre o gênero testemunhal, com especial acento no universo literário e cultural ibero-afro-americano.

Dadas, portanto, suas potencialidades, o gênero testemunhal tem-se revelado um objeto de crescente interesse para as pesquisas antropológicas, literárias, jornalísticas, documentais, afirmando-se como uma fecunda e criativa contribuição à dinamização de história, cultura e literatura. Exemplo disso pode ser conferido na voz testemunhal de Rigoberta Menchú, autora da narrativa $M e$ llamo Rigoberta Menchú y así nació mi conciencia, de 1983. Indígena guatemalteca, ela nasce em 1959, em Chimel, um pequeno povoado quíchua localizado no norte da Guatemala. Tendo-se tornado uma importante ativista política, ela concedeu entrevistas e fez importantes relatos e denúncias para jornalistas, a televisão, o cinema, sobre a violência contra povos indígenas, incluindo seu pai, a mãe e o irmão, cruelmente presos, torturados e mortos pelo exército de seu país.

Em 1983, é lançada, em inglês, a primeira edição do livro, intitulado $I, R i$ goberta Menchú, cujo teor foi mediado e "traduzido" por Elisabeth Burgos De- 
bray. Documento paradigmático do gênero testemunhal na América Latina, o livro exercerá um papel fundamental no sentido de despertar a consciência continental e internacional para os problemas de opressão e exploração de indígenas no contexto guatemalteco, em particular, e no latino-americano, em geral. Em 1992, Rigoberta Menchú recebe o Prêmio Nobel da Paz e se torna internacionalmente conhecida. Na sua voz testemunhal, Alberto Moreiras surpreende "a zona intermediária em que o literário rompe-se em algo mais que não é tanto o real quanto sua possibilidade inesperada". Quiçá uma experiência de "sublime suavizado", expressão mediante a qual ele identifica o próprio cerne da experiência testemunhal, que é também sua reivindicação política mais preeminente (MOREIRAS, 2001: 254).

Marcar lugar, refletir, falar são formas fulcrais de dilatar o espaço simbólico por onde vêm florescendo culturas latino-americanas e africanas. Em comum, ambas trazem, a partir de seus primeiros encontros e confrontos com povos ibéricos, a marca de histórias entrelaçadas e plurais, mas também oprimidas e silenciadas durante alguns séculos de exploração e opressão. São contextos indubitavelmente propícios à enunciação de um compromisso político que encontra no "testemunho" o espaço privilegiado. É justamente nesses contextos que, segundo Valéria de Marco, cabe ao letrado "a função de recolher a voz do subalterno, do marginalizado, para viabilizar uma crítica e um contraponto à 'história oficial', isto é, à versão hegemônica da História" (MARCO, 2004: 2). Nesse sentido, caberia ao letrado mais do que recolher, o compromisso de mediar e transpor o abismo entre as duas instâncias, a exemplo de como se pautou a tarefa mediadora de Elisabeth Burgos Debray, com respeito à voz testemunhal de Rigoberta Menchú.

\section{Um pesadelo recorrente}

Quando postula a necessidade da literatura, das histórias e de como elas criam envolvimento e ampliam nosso mundo, Susan Sontag defende a tarefa moral adotada pelo romancista. Seu papel de recriar a solidariedade humana, de prestar atenção naquilo e naqueles que pedem acolhimento, sem julgamento moral. Em seus posicionamentos de intelectual e escritora, são patentes - além de sua indubitável preocupação estética - os valores éticos, a solidariedade, a coragem 
de denunciar, desde a futilidade, o consumismo, a glutonaria das mídias, até a ideologia homogeneizante que condena ao obsoletismo qualquer tarefa crítica, profética e até subversiva como a dos romancistas e dos intelectuais.

Patente também é sua recusa frente à paradoxal indiferença de cidadãos americanos que, no final do século XX, em plena "era do genocídio", estejam usufruindo no conforto de sua prosperidade, livres do risco de dormir com fome, de ser despedaçados por uma explosão, enquanto, na mesma noite, "em outras partes do mundo, exatamente agora... em Grózni, em Najaf, no Sudão, no Congo, em Gaza, nas favelas do Rio" (SONTAG, 2008: 237). Não deixa de ser relevante e até curioso registrar que, em meio a injustiças, fundamentalismos, desumanidade, perseguições sofridos por ela e seus familiares judeus, Sontag não se deixa corroer pelo ressentimento e nem mesmo pela mágoa. Num discurso de premiação, por exemplo, ela tem a coragem de denunciar a sociedade que lhe confere o prêmio. Essa não deixa de ser uma forma de testemunhar, que faz de Sontag uma espécie de sobrevivente, um corpo estranho em meio à impossibilidade da classe média norte-americana em abrir mão de seu isolamento, de sua segurança, para lançar um olhar ou um gesto solidário em direção àqueles que não "fazem parte".

Dupla encarnação de intelectual e escritora sempre atenta às crises e tensões do mundo contemporâneo, Sontag, posto não ter sido diretamente confrontada pela experiência do holocausto, guarda, não diferentemente de judeus que estiveram no front de guerra, ou confinados em campos de concentração, o pavor de (re)viver ou (re)presenciar cenas de perseguição, tortura e genocídio. Paradoxalmente, esse pavor não tem fundamento, visto sobretudo o fato de ela guardar alentadas lembranças de ter sido "uma tardia beneficiária da diáspora cultural alemã [que teve] a felicidade de conhecer bem alguns refugiados de Hitler incomparavelmente talentosos [...] que os Estados Unidos receberam na década de 30" (SONTAG, 2008: 217). Entretanto, ela teme a retaliação de milhares de soldados nazistas, que foram presos durante e após a Segunda Guerra e que foram levados para um campo de prisioneiros ao norte dos Estados Unidos. Mesmo sendo uma judia cujos familiares já eram seculares havia duas gerações, ela não se livra do pavor de ser perseguida pelos nazistas no presente. Ou seja, décadas depois do fim da guerra.

Eis, nesse sentido, o seu pavor, sob a forma de um pesadelo recorrente: "os soldados nazistas fugiam da prisão, conseguiam chegar até a cidade onde 
eu morava, com minha mãe e minha irmã, e estavam à beira de me matar" (SONTAG, 2008: 217). A despeito de tratar-se de um pesadelo, a intensidade do pavor é o fiel da balança capaz de mensurar o pânico das vítimas que, além da própria experiência de dor, ainda têm que lidar com a culpa de nada ter feito para salvar seus pares. É dessa matéria que se dotam grande parte dos relatos testemunhais. Isso, é claro, quando as experiências vêm à tona.

\section{Armas de papel}

De fato, é recorrente a ocorrência de pesadelos em vítimas de opressão, guerras, prisões e toda a forma de violência. Memórias do cárcere, ou "livro de cadeia", como a ele se refere seu próprio autor, Graciliano Ramos, é exemplar nesse sentido. São tênues as linhas que mesclam o relato ficcional ao documentário testemunhal, mas, de todo o modo, a escrita das Memórias se impõe como a principal forma de resistência e denúncia ao Estado Novo, às torturas e a outras formas de atrocidades impostas aos presos políticos.

As minhas armas, fracas e de papel, só podiam ser manejadas no isolamento.

No íntimo havia talvez o incerto desejo de provocar a nova justiça inquisitorial, perturbar acusadores, exibir em tudo aquilo embutes e patifarias. (RAMOS, 1969, v. 1: 52)

Em correspondência metafórica com os campos de concentração nazifascistas, o cárcere é o "curral de arame farpado", onde os presos, como gado confinado ficam, sob constante tensão, à espera do abate: "Era como se fôssemos gado e nos empurrassem para um banheiro carrapaticida" (v. 1: 124) "Num curral de arame farpado, como bichos, prosseguiu Tamanduá” (v. 2: 16-17).

Ao chegar à primeira prisão onde esteve provisoriamente confinado, o sujeito da memória se impressiona com um esqueleto, "uma ruína de esqueleto" tatuada no antebraço de um funcionário. A descrição do que resta do "estigma", de que o funcionário tentara se livrar, patenteia um processo de autoflagelo que resulta não no apagamento, mas no esfacelamento da macabra tatuagem: "Os restos da infame tatuagem, a marca da ferida iriam persegui-lo para sempre. Era-me impossível desviar os olhos da representação fúnebre" (RAMOS, 1969, v. 1: 194-195). 
Não há como desviar os olhos porque, no corpo de quem olha, está também calcada uma infame tatuagem, que não pode ser extirpada. Que, se caso o fosse, deixaria, de todo modo, cicatrizes abertas, marcas irremovíveis. Identificado seu corpo com o do esqueleto estilhaçado, o eu da memória se reconhece enquanto "carcaça". Assim, se alguém ri, ele crê tratar-se de deboche, dele e de sua carcaça, esse espectro imaginário gerado por temores e privações.

O esqueleto que o moço da rouparia tinha no punho voltou-me ao espírito. Os ácidos não haviam desfeito a medonha tatuagem. Por cima da cicatriz que repuxava a pele e se estendia num desenho róseo, sobressaiam costelas, vértebras, o riso da caveira, As figuras estranhas apinhadas ali riam. Riam para mim como se eu fosse uma carcaça também. (RAMOS, 1969, v. 2: 158)

A imagem vira uma obsessão e se transforma em pesadelo recorrente, onde um espectro desdobrado, espécie de duplo do si mesmo, reproduz a cisão do corpo dilacerado.

Naquele tempo duas obsessões persistiam no delírio teimoso: as pancadas do relógio tomavam forma, ganhavam nitidez e mudavam-se em bichos. Supunha-me dois, um são e o outro doente, e desejava que o cirurgião me dividisse, aproveitasse o lado esquerdo, bom, e enviasse o direito, corrompido, para o necrotério. (RAMOS, 1969, v. 1: 355)

Prestes a ser libertado, o narrador é abordado pelo diretor da Colônia Correcional. Indagado sobre sua profissão, ele revela ser escritor e deixa claro que usará suas "armas de papel” para denunciar torturas, reificação, assassinatos a que foram submetidos os presos políticos (e os comuns), grande parte dos quais condenados sem saberem por que e sem processo, ou seja, sem qualquer proteção legal.

- O senhor é jornalista? [indaga o médico, diretor da Colônia Correcional de Ilha Grande]

- Não senhor. Faço livros. Vou fazer um sobre a Colônia Correcional. Duzentas páginas ou mais. Os senhores me deram assunto magnífico [...]

O médico me enterrou os olhos duros [...] saiu resmungando: 
- A culpa é desses cavalos que mandam para aqui gente que sabe escrever. (RAMOS, 1969, v. 1: 274-278)

O médico tem plena consciência do perigo que encerram as palavras, de sua capacidade em denunciar e modificar realidades. Nesse sentido, um dos episódios mais chocantes dentre os testemunhados por Graciliano em suas memórias do cárcere é o da deportação de duas presas políticas, Olga Prestes e Elisa Berger, ambas judias e suas companheiras de confinamento. Elas foram entregues à gestapo, em razão de "acordo" da ditadura "sem freios" de Getúlio Vargas com os nazistas, como revela a denúncia abaixo. Embora de valor histórico inestimável, o teor da denúncia é lamentável sob o ponto de vista humano, uma humanidade que, em semelhante contexto, acaba reduzida à degradação e à reificação.

Uma noite chegaram-nos gritos medonhos do pavilhão dos primários, informações confusas de cozes numerosas. Aplicando o ouvido, percebemos que Olga Prestes e Elisa Berger iam ser entregues à Gestapo [...] nunca mais foram vistas. Soubemos depois que tinham sido assassinadas num campo de concentração na Alemanha. (RAMOS, 1969, v. 2: 15)

\section{Como um rio subterrâneo}

$\mathrm{Na}$ "era do testemunho", literatura e documentos testemunhais vêm fazendo emergir fontes até então ocultas e impermeáveis que encontram fácil homologia com um rio subterrâneo recentemente descoberto em Roma por geólogos. Trata-se de "um fluxo de água subterrânea que corre entre o cascalho e a areia do antigo curso do Tibre, fechado, acima e abaixo, por duas camadas de terra impermeáveis". Os geólogos vêm apostando na convicção de que, vindo à tona, o rio poderá ser uma fonte renovação e robustecimento da potência energética da capital italiana e seu entorno. ${ }^{4}$ Não diferentemente, quando se

4 http:// ultimosegundo.ig.com.br/mundo/2009/02/10/ rio + subterraneo + descoberto + em + roma + pode + gerar+energia + geotermica $+3963934 . h$ tml. Acesso em 20/03/2009. 
atualizam, acontecimentos desconhecidos ou ocultados patenteiam-se como uma fecunda e criativa contribuição de setores diferenciais - minorias étnicas e sexuais, grupos socioculturalmente subalternos, exilados, imigrantes, vozes oriundas da tradição oral - à dinamização de história, cultura e literatura.

Cerca de uma década após a Segunda Grande Guerra, relatos de cunho testemunhal, dotados de caráter tanto documental como ficcional, começaram a difundir-se nos espaços jornalísticos, jurídicos e editoriais. A despeito da difusão inicial, o testemunho, enquanto gênero narrativo, só atingirá seu melhor fôlego a partir década de 1970. Efeitos de circulação, difusão e credibilidade desse novo gênero serão todavia mais decisivos, sob o influxo dos Estudos Culturais que, ao agenciar o "politicamente correto", fizeram ouvir vozes que começam, então, a irromper nos guetos onde se confinam refugiados, diaspóricos, frontiers, borders, toda a sorte de excluídos a ocupar os interstícios de espaços metropolitanos.

São vozes cuja luta narrativa faz emergir a presença visual das comunidades de minorias, que sobreviveram às margens das nações. Jameson invoca o conceito de "consciência situacional", ou de "alegoria nacional", a obter materialidade e, portanto, a implodir aquela totalidade imaginária de territórios hegemônicos, quando "o contar da história individual e a experiência individual não podem deixar de, por fim, envolver todo o árduo côntar da própria coletividade" (Apud BHABHA, 1998, p. 198-200). Ao prefigurar a fronteira cultural e temporal onde se articulam os pólos opostos e complementares da ambivalência arcaica que embasa o tempo da modernidade, a comunidade intersticial interage, segundo Eric Hobsbawm, como "suplemento antagônico da modernidade: no espaço metropolitano, ele é o território da minoria, colocando em perigo as exigências de civilidade; no mundo transnacional ela se torna o problema de fronteira dos diaspóricos, dos migrantes, dos refugiados" (Apud BHABHA, 1998, p. 198-200).

Dentre as novas vozes, fizeram-se ouvir e ter legitimados seus relatos as de sujeitos testemunhais que começam a emergir de vários mundos subjugados. Pelo curso dessas vozes inauditas, pôde-se ouvir o estranho ar do relato, a fluidez do movimento idiomático, o falar fraturado e quase silencioso de setores marginais à metrópole e à modernidade. Trata-se de uma nova caixa de ressonância apta a difundir e intercambiar documentos, informes, relatos de ocorrências silenciadas de violação, perda e injustiças de toda a ordem, sofri- 
das por exilados, imigrantes, minorias étnicas e sexuais, indígenas expulsos de suas próprias terras, sobreviventes de guerras, ditaduras e genocídio.

Nesse fluxo enunciativo, Beatriz Sarlo identifica a restituição da confiança daquelas vítimas anônimas que, ao narrar sua vida (privada, pública, afetiva, política), recuperam suas lembranças e reanimam a identidade machucada (SARLO, 2007: 18-19). Com percepção ímpar, registra que, sobretudo a partir das denúncias de sobreviventes de campos de concentração, subjetividades emudecidas começam, na Europa, a ter nova voz. Os anos 1970 e 1980, emblemáticos da "guinada lingüística" que tomou de assalto os meios acadêmicos mais prestigiosos do mundo ocidental, começam a assistir a uma histórica e decisiva reviravolta. Trata-se, segundo a aguda percepção de Sarlo, da "guinada subjetiva", agenciadora de um quadro em que "a identidade dos sujeitos voltou a tomar o lugar ocupado, nos anos sessenta, pelas estruturas” (SARLO, 2007: 18-19). Ao se tornar a grande protagonista das décadas em que crimes hediondos foram cometidos por ditaduras latino-americanas, a "guinada subjetiva" desembocou na liberação de autobiografias, documentários, relatos que sancionam o fluxo de vozes machucadas. Sobretudo a partir do exílio, sujeitos testemunhais puderam denunciar e levar à condenação crimes e criminosos engendrados por ditadores e seus aparatos ideológicos. Quase sempre, provas e fontes indiciadoras de crimes foram destruídas por "nossos" criminosos e lançadas ao mar ou em valas comuns. Assim sendo, as peças cabais de resgate do passado foram quase unicamente reconstituídas através de "atos de memória", testemunhados por sobreviventes de crimes, fossem engendrados pelos governos que massacraram índios ou por governos ditatoriais. Beatriz Sarlo acredita que, não fossem esses "atos", nenhuma condenação teria sido possível (SARLO, 2007: 20).

Não obstante ter chancelado perspectivas mais críticas e a possibilidade de desconstrução de forças do poder hegemônico, a mesma guinada subjetiva foi paradoxalmente responsável por desencadear um novo circuito editorial. As biografias e autobiografias, os depoimentos - narrativas testemunhais e mesmo as auto-ajudas - cuja produção e reprodutibilidade se aproximam paulatinamente do ritmo dos jornais diários e das revistas semanais (com eles competindo) se amontoam nas livrarias, nas bancas da esquina, nos pontos venda dos aeroportos, obtendo mais prestígio entre os editores e consumidores do que outras formas não menos relevantes de produção editorial, a exemplo de romances, poesia, filosofia, teoria da literatura e do conhecimen- 
to, não nos esquecendo, aliás, dos dicionários. Essa invasão não chaga a espantar, visto que as grandes dores mesmo dos menos favorecidos pela sorte se transformam em objeto de interesse do mercado financeiro e de desejo para saciar a curiosidade do consumidor.

\section{Experiência e melancolia}

A melancolia do filósofo alemão Walter Benjamin é, há muito, conhecida de seus leitores. Manifesto em muitos de seus escritos, esse estado de ânimo é tão evidente em Benjamin quanto em muitos outros judeus alemães que, como ele, foram vítimas da perseguição nazista, e se tornaram estrangeiros em sua própria pátria. Além dessa razão, é ainda detectável a recusa de Benjamin frente às mudanças capitais da modernidade, dentre as quais a perda da aura, a reprodução técnica, a crescente importância do romance em detrimento das narrativas arcaicas, de caráter oral, cuja exemplaridade pode ser reconhecida no ensaio "O narrador: considerações sobre a obra de Nikolai Leskov” (BENJAMIN, 1994: 197-221).

O narrador oral eleito por Benjamin dota-se de sabedoria e sabe "dar conselhos". No entanto, sua maior capacidade está em conferir transmissibilidade à narrativa e, conseqüentemente, à experiência. Entretanto, sob a perspectiva melancólica e desencantada do filósofo alemão, as narrativas arcaicas por ele emblematizadas estariam em vias de extinção (o ensaio sobre o narrador data de 1934). A "faculdade de intercambiar experiências" estaria em baixa com todas as evidências de que continuaria caindo "até que seu valor desapareça de todo" (BENJAMIN, 1994: 198). Com o final da Primeira Guerra Mundial, Benjamin percebe a avassaladora e irreversível degradação da experiência enquanto valor, bem como as transformações negativas no mundo ético, nas quais ele não via perspectivas de mudança:

No final da guerra, observou-se que os combatentes voltavam mudos do campo de batalha [...] mais pobres em experiência comunicável [...] nunca houve experiências mais radicalmente desmoralizadas que a experiência estratégica pela guerra de trincheiras, a experiência econômica pela inflação, a experiência do corpo pela guerra de material e a experiência ética pelos governantes. (BENJAMIN, 1994: 198) 
Em síntese, finda a Primeira Guerra Mundial, vencidos por humilhação, cansaço e trauma, ex-combatentes emudeceram, recusando-se a comunicar suas experiências e a intercambiá-las. Dez anos depois da guerra, Benjamin vê proliferar e difundir-se uma enxurrada de livros sobre o assunto, os quais, não obstante, nada tinham em comum com a experiência transmitida boca a boca. A relevância de que ainda hoje se dota o ensaio "O narrador..." muito se deve a seu caráter embrionário: malgrado suas contradições, ele não somente intui a emergência de relatos testemunhais enquanto gênero, como também esboça, a partir do conceito de trauma, uma teoria sobre o processo de recusa e mudez do sujeito testemunhal.

\section{O testemunho no contexto ditatorial da América Latina}

Com o foco direcionado para recentes contextos pós-ditatoriais, Beatriz Sarlo avalia os ruidosos efeitos que os relatos testemunhais desencadearam no cenário judiciário de países latino-americanos. Convicta de que não haveria testemunho sem experiência e nem experiência sem sua narração, ela salienta que "a narração da experiência está unida ao corpo e à voz, a uma presença real do sujeito na cena do passado" (SARLO, 2007: 24). Todavia, a experiência só pode ser concebida enquanto tal desde que os vestígios que ela guarda possam ser postos em relato, em "algo vivido que não só se sofre, mas se transmite. Existe experiência quando a vítima se transforma em testemunho" (SARLO, 2007: 26). Testemunho, portanto, a sancionar um novo fôlego a ânimos esmorecidos; a minimizar experiências de choque, redimi-las do emudecimento, do imediatismo ou do esquecimento e transformá-las em algo não somente comunicável, mas também intercambiável (SARLO, 2007: 24).

Em meio às suas reflexões, Sarlo equaciona a desesperança benjaminiana em face do gradativo emudecimento dos retornados da Primeira Guerra Mundial: "Walter Benjamin, diante das conseqüências da Primeira guerra mundial, expôs o esgotamento do relato. É inegável que Benjamin se equivocava quanto à escassez de testemunhos, justamente porque 'a guerra de 1914-8 marca a começo do testemunho de massas'." (SARLO, 2007: 25). A partir de postulações benjaminianas, Beatriz Sarlo retoma acontecimentos da Segunda Guerra, que consistiriam na prova irrefutável da relação inseparável 
entre experiência e relato, "algo vivido que não só se sofre, mas se transmite". Nesse sentido, existiria experiência, "quando a vítima [a] transforma em testemunho" (SARLO, 2007: 26). Em outras palavras, a “experiência” só poderá ser concebida enquanto tal, quando puder ser posta em "relato", ao qual é tributável o efeito reparador da subjetividade. E é esse aspecto que Sarlo salienta para postular a necessidade cabal do testemunho como instrumento de cura para as identidades em perigo (SARLO, 2007: 51).

Ao desconstruir o que considera equivocado, sobretudo no que se refere ao "emudecimento" dos retornados da guerra, Sarlo justifica que o eclipsamento de relatos acerca de experiências significativas já vinha acontecendo muito antes "do choque da guerra e do choque técnico da modernidade, com o surgimento do romance, que tomou o lugar das 'formas artesanais' de transmissão, isto é, enraizadas no imediatismo da voz, em que o perigo cercava a experiência (possibilitava-a) em vez de habitar seu centro" (SARLO, 2007: 27). Ela guarda ainda a convicção de que contrariamente ao vaticínio benjaminiano, sobreviventes de guerras, ditaduras e outras ocorrências-limite dispõem-se cada vez mais a testemunhar suas experiências de violação e trauma, seja através de documentários, seja pela ficção ou pela mescla de ambos.

\section{A travessia da experiência para o relato em Grande sertão: veredas}

Chancelado pelo relato, o processo que sanciona a passagem dos traumas

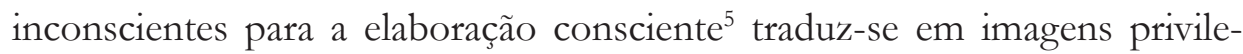
giadas de obras literárias, que, malgrado seu empenho em representar o real, nunca o farão com fidelidade. Em síntese, poder-se-ia afirmar que semelhantes imagens se aproximam muitas vezes do acontecimento representado, sem

\footnotetext{
5 A noção de trauma pode ser examinada em Freud, segundo o qual a repetição dos choques torna-se onipresente no dia-a-dia, e a interiorização desta experiência faz com que a realidade passe a ser vista como catástrofe, o que abala a concepção tradicional de uma representação capaz de dar "conta" do real. No conceito freudiano, o trauma "é o resultado de uma ruptura da proteção contra as excitações do mundo exterior. [...] Um acontecimento (externo) como um trauma está destinado a provocar um distúrbio em grande escala no funcionamento da energia do organismo e a colocar em movimento todas as medidas defensivas possíveis". O afloramento daquilo que estava recalcado, possibilitando sua posterior representação, ou a passagem do "real ao simbólico", é o que Freud conceitua como "retorno do recalcado”. Ver em Freud (1975: 170; 1976: 277-281).
} 
nunca, contudo, chegar a tocá-lo. Tal limitação é literariamente representada por meio de imagens epifânicas, imagens de fulgor, de súbita revelação, ao passo que seguidas de súbito apagamento, trazendo fugazmente à presença experiências de sofrimento, anomia, desterramento, guerra, mortes, luto, melancolia e culpa; e, em não raras vezes, de descoberta, superação, transcendência, encontro consigo mesmo e com o outro. Contudo, são apenas fulgurações a resvalar, sem contudo tocar o objeto perdido. Este emerge como fragmento, lacuna, algo como o "vazio sem vaso", de Drummond; ou a "ausência", na qual Foucault foi capaz de divisar o signo do vivido/perdido a convergir, paradoxalmente, para o lugar fundador do discurso (FOUCAULT, 2006: 31-36).

Tendo essas reflexões em vista, pode-se melhor compreender e mesmo compartilhar os temores, a culpa e os traumas de Riobaldo, narrador-protagonista do romance Grande sertão: veredas, de Guimarães Rosa. Como muitos indivíduos empíricos, Riobaldo é um ser ficcional que sofre em razão de culpa, temores, lembranças traumáticas. Os fantasmas riobaldianos se patenteiam reiterada e recursivamente ao longo do romance e nele se condensam, sob este aforismo: "Viver é muito perigoso". Por outro lado, a repetição traz o vertiginoso efeito do deslizamento significante, fazendo aflorar a consciência de que o perigo é incontornável, visto estar na esfera do "real", daquilo que ainda não se sabe. Ou seja, daquele enigma irrespondível que nos surpreende no meio do caminho. É justamente a aventura de atravessar o perigo que ronda o viver, que irá ensinarnos a viver, a refletir, a conhecer, enfim, a reconhecer o vivido enquanto tal. Paradoxal e temerariamente, aprende-se a viver a posteriori, depois que já se passou pelo acontecimento, pelas vias e relações perigosas. Viver é muito perigoso porque se vive no fluxo imprevisto do vir-a-ser.

Riobaldo é o "Mestre é quem de repente aprende". No entanto, só aprende mesmo porque, não obstante o perigo e o risco de viver, arrisca-se a atravessar pastos que carecem de fecho, a enfrentar "o diabo na rua no meio do redemoinho", a fazer pactos e cometer traições para cumprir sua missão heróica de acabar com "o mal da jagunçagem", uma evidente alegoria do sertão-mundo. No entanto, sua maior façanha é a descoberta, compartilhada com seu entrevistador - homem de "suma doutoração" - de que viver é muito perigoso, porque ainda não se sabe. "Por que aprender-a-viver é que é o viver, mesmo" e, para tanto "carece de ter coragem". 
Ao trilharmos caminhos desconhecidos ou atravessarmos de uma para outra margem de um rio, estamos na ordem do real, frente ao desconhecido, ao insondável. O tempo da travessia é o tempo da experiência, sobre o qual só teremos oportunidade de refletir depois que já atravessamos, ou melhor, depois de termos corrido o risco suficiente para sermos confrontados pelo desconhecido. Como Édipo, somos limitados pela cegueira e sempre ameaçados por nossas falhas trágicas:

Eu atravesso as coisas - e no meio da travessia não vejo! só estava era entretido na idéia dos lugares de saída e de chegada". Assaz o senhor sabe: a gente quer passar um rio a nado, e passa; mas vai dar na outra banda é num ponto muito mais embaixo, bem diverso do em primeiro se pensou. Viver nem não é muito perigoso? (ROSA, 1984: 33)

Superar a dor, vencer o trauma, viver o luto, dizer o indizível, representar o irrepresentável. Ser capaz de ler temores, bordejar cicatrizes e lacunas é a grande arte do testemunho, e é, através dela, sob sua mediação, que nos é dado dizer o que, até então, não pôde ainda ser dito. Porque o tempo da travessia é o tempo da experiência, sobre o qual só teremos oportunidade de refletir depois que já atravessamos, ou seja, depois que passamos do vivido ao relato, da experiência à vivência. Assim sendo, o tempo do vivido é o tempo da guerra, do trauma, do real em estado bruto, do não elaborado, como bem o percebeu Riobaldo, na passagem já anteriormente citada: "Digo: o real não está na saída nem na chegada: ele se dispõe para a gente é no meio da travessia" (ROSA, 1984: 60).

\section{Um corpo que falta, uma voz que fala}

Uma recorrente citação sobre a impossibilidade de escrever depois de eventos traumáticos é esta frase de Adorno: "A crítica cultural defronta-se com o último degrau da dialética entre cultura e barbárie: é barbárie escrever um poema depois de Auschwitz, e isso corrói o conhecimento que afirma por que hoje se tornou impossível escrever poemas" (ADORNO, 1998). Guimarães Rosa, que conheceu de perto a guerra e o genocídio dos judeus, que correu 
risco de vida quando internado pela Gestapo em Baden Baden-Alemanha, parece não aceitar semelhante interdito. Emblemáticas, neste sentido, são as passagens do real para o relato, metaforicamente encenadas nas travessias de Riobaldo em Grande sertão: veredas.

Malgrado os traumas da pobreza, da humilhação sofrida enquanto filho bastardo e depois enquanto jagunço, remarcado como gado, da dívida decorrente de seu pacto com o diabo, de perda de Diadorim e da culpa em face de sua morte, Riobaldo Tatarana, do romance rosiano, é um sujeito em processo, a atravessar o espaço minado das guerras jagunças, o fantasma de inimigos visíveis e invisíveis, a culpa da amada, que morre, (imaginariamente) em seu lugar no combate. O maior embate desse herói bastardo é, contudo, de si contra si mesmo, da coragem contra o medo, da luta narrativa contra a intraduzibilidade do vivido. Luta contra o luto e contra o imponderável, num esforço quase vão de torção para comandar as palavras, obrigando-as a negociar com o indizível, o irrepresentável do real.

"Se o trabalho do luto só pode ser levado a cabo através da narração de uma história, o dilema [do relato] reside no caráter incomensurável e irresolúvel dessa mediação entre experiência e narrativa." (AVELAR, 2003: 236). Ao sujeito do relato restaria o esforço de tradução ou negociação no sentido possível de colocar-se "num mais ou numa falta, excessiva ou impotente para capturar o luto em toda a sua dimensão" (AVELAR, 2003: 236). Como traduzir a ausência da amada cuja morte é inassimilável e, portanto, irrepresentável? Como bordejar a morte de um ser amado, esse absurdo incomensurável, esse acontecimento irredutível a qualquer tentativa de metaforização? Para o real, as palavras sempre faltam, e Riobaldo, gaguejante, paralisado, frente ao corpo da amada morta, só faz confirmá-lo:

Diadorim tinha morrido - mil-vezes-mente - para sempre de mim; e eu sabia, e não queria saber, meus olhos marejavam (ROSA, 1984: 557) [...] ... Não escrevo, não falo! - para assim não ser: não foi, não é, não fica sendo! Diadorim... [...] Tal que disse, doidava. Recaí no marcar do sofrer. Em real me vi [...] Fim que foi... (ROSA, 1984: 561)

Não sendo possível desencantar Diadorim no real irremediável, pode-se, contudo, intercambiar a história vivida com a versão chancelada pelo relato. Ou, em último caso, fazer um outro pacto, ainda que ficcional, para além daquele outro pacto entabulado com o diabo. No real, a culpa tenderá a repe- 
tir-se porque, sendo irreversível, o acontecimento vivido é irreparável. É na linguagem, tão-somente na própria linguagem, conforme o postula De Man, que a 'culpa' se resolve" (apud FOUCAULT, 2006: 16). Nesse sentido, um dos saltos a que se lança o Mestre Riobaldo consiste justamente na aprendizagem de que a ausência é o lugar onde principia o discurso, o resgate da humanidade ferida, sua travessia:

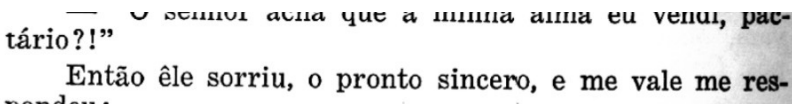
pondeu: - "Tem cisma não. Pensa para diante. Comprar ou vender, às vêzes, são as ações que são as quase iguais..."

E me cerro, aqui, mire e veja. Isto não é o de um relatar passagens de sua vida, em tôda admiração. Conto o que fui e vi, no levantar do dia. Auroras.

Cerro. O senhor vê. Contei tudo. Agora estou aqui, quase barranqueiro. Para a velhice vou, com ordem e trabalho. Sei de mim? Cumpro. O Rio de São Francisco que de tão grande se comparece - parece é um pau grosso, em pé, enorme... Amável o senhor me ouviu, minha idéia confirmou: que o Diabo não existe. Pois não? 0 senhor é um homem soberano, circunspecto. Amigos somos. Nonada. O diabo não há! É o que eu digo, se fôr... Existe é homem humano. Travessia.

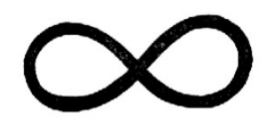

Dizer e escrever os acontecimentos traumáticos é a saída simbólica para sancionar a travessia do vivido para a vivência, reeditar corpos esfacelados, fazer do medo a vau da coragem. Vencer o medo do passado e libertar-se para o futuro são desafios cabais que a literatura de Guimarães Rosa propõe para o novo século em que uma geopolítica de alteridades, etnias e desejos diferenciais possam, com menos atrito e sem tanto receio, fazer frente ao universo de poderes hegemônicos. O sertão do tamanho do mundo que, na alegoria rosiana, se encontra em toda a parte, patenteia-se como um espaço de relações heterogêneas, onde os pastos carecem de fechos, sendo franqueadas fronteiras e margens. Onde sobreviventes de toda a sorte de violência podem criar cantigas, poemas, 
narrativas eivadas na experiência para intercambiar experiências, para lembrar ou para esquecer seus mortos. Lembrar ou esquecer o "diabo", que torna "muito perigoso" o viver; lembrar ou esquecer os "currais de arame farpado" do Estado (Novo) brasileiro; ou os campos de Auschwitz.

Para Antonio Beneti, Délio Fantini e Jaime Ginsburg.

Belo Horizonte, abril de 2009.

\section{Referências Bibliográficas}

ADORNO, T.W. Crítica cultural e sociedade. In: Prismas. Trad. Augustin Wernet e Jorge Mattos Brito de Almeida. São Paulo: Ática, 1998.

AVELAR, Idelber. Alegorias da derrota: a ficção pós-ditatorial e o trabalho do luto na América Latina. Belo Horizonte: Ed. UFMG, 2003.

BAUMAN, Zygmunt. Confiança e medo na cidade. Trad. Miguel Serras Pereira. Lisboa: Relógio D’Água, 2005.

BENJAMIN, Walter. O narrador: considerações sobre a obra de Nikolai Leskov. In: Magia e técnica, arte e política: ensaios sobre literatura e história da cultura. São Paulo: Brasiliense, 1994.

BENJAMIN, Walter. Sobre alguns temas em Baudelaire. In: Charles Baudelaire: um lírico no auge do capitalismo. Trad. Jose C. M. Barbosa et al. São Paulo: Brasiliense, 1998.

EWALD, François. O cuidado com a verdade. Entrevista com M. Foucault, Le Magazin. In: ESCOBAR, Carlos Henrique (Org.). Michel Foucault (1926-1984). O Dossiê: últimas entrevistas. Rio de Janeiro: Livraria Taurus Editora, 1984, p. 72-75.

FELDMAN, Shoshana. Educação e crise, ou as vicissitudes do ensinar. In: NESTROVSKI, Arthur; SELIGMANN-SILVA, Márcio (Org.). Catástrofe e representação. São Paulo: Escuta, 2000.

FOUCAULT, Michel. O que é um autor? Trad. António Fernando Cascais. Lisboa: Nova Veja, 2006.

FREUD, Sigmund. Moisés e o monoteísmo. In: Edição standard brasileira das obras psicológicas completas de Sigmund Freud, v. XXIII. Rio de Janeiro: Imago, 1975.

O Estranho. In: Edição standard brasileira das obras psicológicas completas de Sigmund Freud, v. XVII. Rio de Janeiro: Imago, 1976.

GINSBURG, Jaime. Linguagem e trauma na escrita do Testemunho. Disponível em: < http://www.msmidia.com/conexao/3/cap6.pdf > . Acessado em 30/03/2009.

HEIDEGGER, Martin. O princípio da identidade. In: Heidegger. São Paulo, Abril Cultural, 1984 (Col. “Os Pensadores”). 
MARCO, Valéria de. A literatura de testemunho e a violência de Estado. Lua Nova: Revista de Cultura e Política, São Paulo, n. 62, 2004.

MOREIRAS, Alberto. A aura do testemunho. A exaustão da diferença: a política dos estudos culturais latino-americanos. Trad. Eliana L. de Lima e Gláucia Renate. Belo Horizonte: Ed. UFMG, 2001.

ONDAATTJE, Michael. O paciente inglês. Trad. Rubens Figueiredo. São Paulo: Companhia das Letras, 2007.

RAMA, Angel. Dez problemas para o romancista latino-americano. In: AGUIAR, Flávio; VASCONCELOS, Sandra Guardini T. (Org.). Angel Rama: literatura e cultura na América Latina. São Paulo: Edusp, 2001.

RAMOS, Graciliano. Memórias do cárcere. Rio de Janeiro: Record, 1969.

ROSA, João Guimarães. Grande sertão: veredas. 21. ed. Rio de Janeiro: Nova Fronteira, 1984.

SARLO, Beatriz. Tempo passado: cultura da memória e guinada subjetiva. Trad. Rosa Freire d'Aguiar. Belo Horizonte: Ed. UFMG; São Paulo: Companhia das Letras, 2007.

SONTAG, Susan. Ao mesmo tempo: ensaios e discursos. Trad. Rubens Figueiredo. São Paulo: Companhia das Letras, 2008. 